\title{
Skin changes in chronic kidney disease
}

\section{Zmiany skórne w przewlekłej chorobie nerek}

Joanna M. Przepiórka-Kosińska, Katarzyna M. Chyl-Surdacka, Joanna Bartosińska, Dorota Krasowska, Grażyna Chodorowska

Department of Dermatology, Venereology and Paediatric Dermatology, Medical University of Lublin, Poland

Katedra i Klinika Dermatologii, Wenerologii i Dermatologii Dziecięcej Uniwersytetu Medycznego w Lublinie, Polska

Dermatol Rev/Przegl Dermatol 2017, 104, |42-153 DOI: https://doi.org/l0.5 I |4/dr.2017.67389

\author{
CORRESPONDING AUTHOR/ \\ ADRES DO KORESPONDENCJI: \\ lek. Joanna M. Przepiórka-Kosińska \\ Katedra i Klinika Dermatologii, \\ Wenerologii i Dermatologii \\ Dziecięcej \\ Uniwersytet Medyczny w Lublinie \\ ul. Radziwiłłowska 13 \\ 20-080 Lublin, Polska \\ tel.: +48 815328415 \\ e-mail: \\ joannaprzepiorkakosinska@umlub.pl
}

\begin{abstract}
Chronic kidney disease causes skin changes which may sometimes be the first sign of kidney failure. Specific skin changes include acquired perforating dermatosis, porphyria cutanea tarda, pseudoporphyria, calcinosis and nephrogenic systemic fibrosis. The majority of patients present with cutaneous manifestations which are classified as nonspecific, including xerosis, pruritus, pigmentation disturbances, nail plate abnormalities, uraemic frost and gynaecomastia. Treatment improving kidney function (dialysis therapy or kidney transplantation) also leads to the resolution of skin lesions.
\end{abstract}

\section{STRESZCZENIE}

Przewlekła choroba nerek powoduje zmiany skórne, które niejednokrotnie mogą być pierwszym objawem niewydolności nerek. Do swoistych zmian skórnych należą: nabyta perforująca dermatoza, porfiria skórna późna, pseudoporfiria, zwapnienia oraz uogólnione nerkopochodne włóknienie. Zmiany zaliczane do objawów nieswoistych, takie jak suchość skóry, świąd skóry, zmiany jej zabarwienia, nieprawidłowości dotyczące płytek paznokciowych, szron mocznicowy oraz ginekomastia, są spotykane u większości pacjentów. Leczenie powodujące poprawę wydolności nerek (dializoterapia lub przeszczepienie nerki) prowadzi jednocześnie do złagodzenia lub ustąpienia objawów skórnych.

Key words: chronic kidney disease, kidney failure, cutaneous manifestations, acquired perforating dermatosis, porphyria cutanea tarda, pseudoporphyria, nephrogenic systemic fibrosis, calciphylaxis.

Słowa kluczowe: przewlekła choroba nerek, niewydolność nerek, objawy skórne, nabyta perforująca dermatoza, porfiria skórna późna, pseudoporfiria, uogólnione nerkopochodne włóknienie, kalcyfilaksja. 


\section{INTRODUCTION}

Chronic kidney disease (CKD) affects $8 \%$ to $16 \%$ of the adult population worldwide and is associated with multiple complications [1]. Patients with CKD present with a variety of cutaneous symptoms ranging from minor skin conditions without a significant effect on normal functioning to severe disorders having a negative impact on the activities of daily living $[2,3]$. It is not uncommon for skin changes to be the first important sign of kidney disease, and nearly all patients with end-stage renal disease (ESRD) have at least one dermatological manifestation [4-6].

Chronic kidney disease may be associated with both specific and non-specific skin abnormalities [25]. Commonly observed non-specific changes which may also accompany other diseases and disorders (including arterial hypertension, lipid disturbances and hyperglycaemia) include: xerosis, pruritus, pigmentation disturbances, nail plate abnormalities (such as "half-and-half nails"), uraemic frost and gynaecomastia. Specific skin changes in CKD include acquired perforating dermatosis, bullous diseases (such as porphyria cutanea tarda and pseudoporphyria), calcinosis and nephrogenic systemic fibrosis $[2,3]$. From the list given above, the most common skin changes occurring in CKD are: xerosis, pruritus, hyperpigmentation and bullous diseases - as well as perforating dermatoses and skin eruptions resulting from increased blood calcium levels [3-5, 7-9].

\section{NON-SPECIFIC SKIN CHANGES IN PATIENTS WITH END-STAGE RENAL DISEASE}

Xerosis affects approximately $85 \%$ of patients with ESRD, and it is particularly severe in the period before the initiation of dialysis therapy $[2,3,10]$. Although the pathomechanism is not entirely clear, similarly to other causes of dry skin it is known to involve a decreased amount of water in the stratum corneum, impaired sebum production and perspiration secondary to adnexal atrophy and altered composition of epidermal lipids. At the same time, the effect of increased urea levels on xerosis remains unclear $[2,3,10,11]$. Interestingly, xerosis occurs more frequently in patients treated with peritoneal dialysis than haemodialysis [10]. The condition affects predominantly the trunk and extensor parts of the extremities, without a tendency to resolve spontaneously, even though it may exhibit seasonal variation in severity $[2,10]$. Helpful therapeutic options include creams with $5-10 \%$ urea and $2-3 \%$ salicylic acid [3]. Appropriate skin care, especially proper moisturization, is also essential to mitigate symptoms of xerosis $[2,10]$. Epidermal barrier dysfunction makes the skin more susceptible to the adverse effects of external

\section{WPROWADZENIE}

Przewlekła choroba nerek (PChN) dotyka od 8\% do $16 \%$ osób dorosłych na świecie i wiąże się z rozwojem licznych powikłań [1]. U pacjentów z PChN stwierdza się występowanie różnych objawów skórnych - od zmian niemających istotnego wpływu na prawidłowe funkcjonowanie aż po ciężkie, utrudniające wykonywanie codziennych czynności $[2,3]$. Niejednokrotnie zmiany skórne mogą być pierwszym ważnym sygnałem choroby nerek, a u niemal wszystkich pacjentów ze schyłkową niewydolnością nerek (SNN) obserwuje się co najmniej jeden objaw dermatologiczny [4-6].

W PChN wyróżnia się swoiste i nieswoiste zmiany skórne [2-5]. Do powszechnie obserwowanych zmian nieswoistych, mogących towarzyszyć również innym chorobom i zaburzeniom (m.in. nadciśnieniu tętniczemu, zaburzeniom lipidowym i hiperglikemii), należą: suchość, świąd i zmiana zabarwienia skóry, nieprawidłowości dotyczące płytek paznokciowych (takie jak half-and-half nails), szron mocznicowy oraz ginekomastia. Do swoistych zmian skórnych w PChN zalicza się: nabytą perforującą dermatozę, choroby związane $\mathrm{z}$ tworzeniem pęcherzy (takie jak porfiria skórna późna, pseudoporfiria), zwapnienia oraz uogólnione nerkopochodne włóknienie [2, 3]. Spośród wymienionych zmian skórnych w PChN najczęściej stwierdza się: suchość skóry, świąd, przebarwienia oraz choroby przebiegające $\mathrm{z}$ tworzeniem pęcherzy, dermatozy perforujące i wykwity będące następstwem zwiększonego stężenia wapnia we krwi [3-5, 7-9].

\section{NIESWOISTE ZMIANY SKÓRNE U PACJENTÓW ZE SCHYŁKOWĄ NIEWYDOLNOŚCIĄ NEREK}

Suchość skóry występuje u ok. 85\% pacjentów ze SNN i jest szczególnie nasilona w okresie przed rozpoczęciem dializoterapii $[2,3,10]$. Chociaż patomechanizm jest nieznany, wiadomo, że podobnie jak w przypadku innych przyczyn suchości skóry wynika ze zmniejszenia zawartości wody w warstwie rogowej naskórka, upośledzenia wydzielania łoju i potu wskutek zaniku przydatków oraz zaburzeń w składzie lipidów naskórkowych. Jednocześnie wpływ podwyższonego stężenia mocznika na suchość skóry jest niejasny $[2,3,10,11]$. Interesujące jest, że suchość skóry częściej dotyka pacjentów poddanych dializom otrzewnowym niż hemodializom [10]. Suchość skóry obejmuje przede wszystkim tułów i wyprostne części kończyn, bez tendencji do samoistnego ustępowania, chociaż można zaobserwować sezonową zmienność jej nasilenia $[2,10]$. W leczeniu pomocne są kremy z 5-10\% mocznikiem oraz z 2-3\% kwasem salicylowym [3]. Ważna jest prawidłowa pielęgnacja skóry, szczególnie jej odpowiednie nawilżanie $[2,10]$. Ze względu na za- 
factors such as temperature changes and chemical agents [10]. Symptoms caused by xerosis are markedly relieved after kidney transplantation $[3,10]$.

Pruritus is another symptom accompanying ESRD and affecting approximately $40-50 \%$ of patients $[2,3$, $6,12-14]$. The incidence of pruritus has now been reduced, however prior to the introduction of dialysis therapy it was about $80 \%$ [2,12]. Pruritus is known to have a significant adverse effect on the quality of life, which also applies to patients with $\operatorname{CKD}[3,6,7]$. Before attributing pruritus to this pathomechanism, other potential causes of the condition must be excluded [2]. The risk factors for pruritus in this group of patients include male gender, old age, high level of $\beta 2$-microglobulin, calcium and phosphates, and hypersensitivity reactions to dialysis membranes $[3,6,9]$. The pathogenesis of CKD-associated pruritus involves a number of factors including xerosis, hypervitaminosis A, electrolyte disorders (hypercalcaemia, hyperphosphataemia, hypermagnesaemia), secondary hyperparathyroidism, peripheral neuropathy and increased plasma concentrations of $\beta$-endorphins, $\mu$-receptor antagonists, interleukin 2 (IL-2), IL-6, C-reactive protein (CRP), and elevated mast cell count in the skin [2, 3, 6, 9-14]. Razeghi et al. [15] showed that increased ferritin levels and reduced albumin and transferrin levels in patients with CKD were associated with more severe skin itch [15]. Pruritus typically affects the skin on the back, shoulders, anterior surface of the chest and face $[2,4,6,7,12]$. Patients also develop skin lesions secondary to persistent scratching, including excoriations, secondary bacterial superinfections, hyperpigmentation and hypopigmentation. Treatment is prescribed on an individual basis, and comprises proper skin moisturization in every patient $[2,6]$. Antihistamine drugs often prove ineffective [3]. In some cases, good effects may be achieved with topical glucocorticoids under occlusion, retinoids, $0.25 \%$ capsaicin and cryotherapy [3,6]. Gabapentin or pregabalin may be effective in systemic treatment [2]. Some authors also highlight the therapeutic efficacy of UVB phytotherapy. Similarly to xerosis, pruritus is reduced or eliminated completely after kidney transplantation [6].

Dermatological manifestations commonly observed in patients with CKD include skin pigmentation disorders [6, 7]. Approximately $40 \%$ of patents have pale skin, which may be a consequence of anaemia due to deficiencies of iron and folic acid [2, 3, 6, 7, 11]. Erythropoietin treatment and vitamin and mineral supplementation are recommended as a therapeutic option $[2,11]$. The accumulation of fat-soluble pigments (i.e. carotenoids or urobilinogen) leads to yellowish discolouration of the skin surface, and the deposition of haemosiderin makes the skin appear brownish-gray [2, burzenie bariery naskórkowej skóra staje się bardziej podatna na szkodliwy wpływ czynników zewnętrznych, ti. zmiany temperatury oraz czynniki chemiczne [10]. Objawy wynikające z suchości skóry zdecydowanie zmniejszają się po przeszczepieniu nerki $[3,10]$.

Świąd skóry, kolejny objaw towarzyszący SNN, występuje u ok. 40-50\% pacjentów [2, 3, 6, 12-14]. Częstość jego występowania obecnie się zmniejszyła, przed wprowadzeniem dializoterapii wynosiła ok. 80\% [2, 12]. Jak wiadomo, świąd znacznie obniża jakość życia, co dotyczy również pacjentów z PChN [3, 6, 7]. Przed ustaleniem rozpoznania świądu na tym podłożu należy wykluczyć inne jego przyczyny [2]. Do czynników ryzyka świądu w tej grupie chorych zalicza się: płeć męską, starszy wiek, duże stężenie $\beta 2$-mikroglobuliny, wapnia i fosforanów, a także wystąpienie reakcji alergicznej związanej ze składnikami błon dializacyjnych $[3,6,9]$. Patogeneza świądu w PChN jest złożona, bierze w niej udział wiele czynników, w tym suchość skóry, hiperwitaminoza A, zaburzenia elektrolitowe (hiperkalcemia, hiperfosfatemia, hipermagnezemia), wtórna nadczynność przytarczyc, obwodowa neuropatia, a także wzrost stężenia w osoczu $\beta$-endorfin, antagonistów receptora $\mu$, interleukiny 2 (IL-2), IL-6, białka C-reaktywnego (CRP) oraz liczby komórek tucznych w skórze [2, 3, 6, 9-14]. Razeghi i wsp. [15] zaobserwowali, że większe stężenie ferrytyny oraz zmniejszone stężenie albumin $i$ transferyny $u$ pacjentów z PChN wiązało się z występowaniem bardziej nasilonego świądu [15]. Świąd najczęściej obejmuje skórę pleców, ramion, przedniej powierzchni klatki piersiowej oraz twarzy $[2,4,6,7,12]$. U pacjentów stwierdza się również zmiany skórne powstałe wtórnie do uporczywego drapania, tj. przeczosy, wtórne nadkażenia bakteryjne, przebarwienia i odbarwienia. Metodę leczenia dobiera się indywidualnie z uwzględnieniem odpowiedniego nawilżania skóry u każdego pacjenta [2, 6]. Leki przeciwhistaminowe są często nieskuteczne [3]. W niektórych przypadkach pomocne może być leczenie miejscowe glikokortykosteroidami w okluzji, retinoidami, 0,25\% kapsaicyną i krioterapią [3, 6]. W leczeniu ogólnym dobre efekty uzyskuje się przy zastosowaniu gabapentyny lub pregabaliny [2]. Część autorów podkreśla skuteczność fototerapii UVB. Podobnie jak w przypadku suchości skóry świąd ulega złagodzeniu lub ustępuje po przeszczepieniu nerki [6].

Jednym z często obserwowanych objawów dermatologicznych u pacjentów z PChN są zmiany zabarwienia skóry $[6,7]$. U ok. 40\% chorych obserwuje się bladość skóry, która może być wynikiem niedokrwistości z niedoboru kwasu foliowego lub żelaza [2, $3,6,7,11]$. Wskazane jest podawanie erytropoetyny oraz uzupełnianie witamin i składników mineralnych $[2,11]$. Gromadzenie barwników rozpuszczalnych w tłuszczach (np. karotenoidów lub urobilinogenu) powoduje zażółcenie powłok skórnych, a odkładanie 
$3,6,7,11]$. Approximately $20 \%$ of patients are affected by hyperpigmentation, which is most likely linked to an increased level of melanotropin (MSH) [2, 6, 8, 11]. Patients are advised to reduce their exposure to UV radiation and use sunscreens as a means of prophylaxis $[2,6]$. Furthermore, the severity of hyperpigmentation-type changes has been observed to rise with increased duration of dialysis treatment $[4,6,11]$. The literature also reports cases of skin hypopigmentation in patients with CKD [5]. On account of blood platelet dysfunction such patients are affected by blood extravasations which have a tendency to resolve after dialysis treatment is initiated $[2,3,6]$.

Depending on the literature source, half-and-half nails, also known as Lindsay's nails, occur in 6.9-20\% of CKD patients $[2,3,5,6,16]$. The mechanism underlying their development is not fully understood, however similarly to the pathogenesis of hyperpigmentation, it is suspected to involve an elevated level of MSH $[2,3,6,9,16,17]$. Clinically, in half-and-half nails the proximal portion of the nail is white, with normal or brown discolouration seen distally $[2,6,9$, $11,16,17]$. The disorder is more common on fingernails than toenails [6]. There is no effective treatment modality, however in some patients half-and-half nails have been shown to resolve after kidney transplantation $[2,3,6,9,11,17]$. Chronic kidney disease may also be accompanied by hypoalbuminaemia manifesting as the so-called Muehrcke's lines, i.e. white transverse fingernail lines which, owing to changes in the nail bed, do not disappear as the nail plate grows $[6,11,16,18]$.

Excessive hair loss is secondary to a multitude of chronic diseases. It is also seen in patients with CKD, where one additional notable observation is the loss of hair on the lower extremities $[5,8,11]$.

Approximately $3 \%$ of patients with ESRD present with uraemic frost $[3,9]$. The lesions appear as a white deposit on the skin resulting from the elimination of excess urea by the sweat glands. The symptom has been observed to resolve after the initiation of dialysis treatment $[3,9,17]$.

Patients with CKD may also develop gynaecomastia secondary to an increased secretion of prolactin. Prolactin concentrations in excess of $30 \mu \mathrm{g} / 1$ contribute directly to renal function impairment. In women, hyperprolactinaemia contributes to inhibiting the release of the luteinizing hormone and the folliculotropic hormone, thus reducing the production of oestrogens and progesterone and ultimately leading to the development of acne and/or hirsutism. Moreover, insulin resistance associated with hyperprolactinaemia may contribute to the development of acanthosis nigricans [3].

Other symptoms seen in patients with CKD are cutaneous inflammatory changes localized in the złogów hemosyderyny - zmiany zabarwienia skóry na kolor szaroziemisty $[2,3,6,7,11]$. U ok. $20 \%$ chorych obserwuje się hiperpigmentację, co najprawdopodobniej ma związek ze zwiększonym stężeniem melanotropiny (MSH) $[2,6,8,11]$. Zaleca się ograniczenie ekspozycji na promieniowanie ultrafioletowe (UV) i profilaktyczne stosowanie filtrów przeciwsłonecznych [2, 6]. Ponadto zaobserwowano, że zmiany $\mathrm{w}$ postaci hiperpigmentacji nasilają się z czasem trwania dializoterapii $[4,6,11]$. W piśmiennictwie obecne są również doniesienia o występowaniu u pacjentów z PChN odbarwień skóry [5]. Z powodu zaburzeń funkcji płytek krwi stwierdza się u tych chorych występowanie wybroczyn, które mają tendencję do ustępowania po rozpoczęciu dializoterapii $[2,3,6]$.

Zmiany na płytkach paznokciowych typu half-and-half nails, zwane też paznokciami Lindsaya, wg różnych źródeł występują u ok. 6,9-20\% pacjentów z PChN $[2,3,5,6,16]$. Mechanizm ich powstania nie jest znany, chociaż podobnie jak w patogenezie przebarwień podejrzewa się udział podwyższonego stężenia MSH [2, 3, 6, 9, 16, 17]. Klinicznie zmiany mają postać prawidłowego lub brunatnego zabarwienia dystalnych części paznokci oraz zbielenia części proksymalnych [2, 6, 9, 11, 16, 17]. Częściej dotyczą płytek paznokciowych rąk niż stóp [6]. Nie ma skutecznego leczenia, chociaż u części chorych obserwowano ich ustępowanie po przeszczepieniu nerki $[2,3,6,9,11,17]$. Przewlekłej chorobie nerek może towarzyszyć hipoalbuminemia, w przebiegu której obserwuje się tzw. linie Muehrckego, czyli białe poprzeczne prążki, które w związku ze zmianami w łożysku paznokcia utrzymują się niezależnie od wzrostu płytki paznokciowej $[6,11,16,18]$.

Nadmierne wypadanie włosów stwierdza się w przebiegu wielu chorób przewlekłych, również u pacjentów z PChN, u których dodatkowo zwraca uwage ubytek owłosienia na kończynach dolnych $[5,8,11]$.

U ok. 3\% pacjentów ze SNN występuje szron mocznicowy [3, 9]. Zmiany mają postać białego osadu na skórze, będącego następstwem wydalania przez gruczoły potowe nadmiaru mocznika. Po wdrożeniu dializ obserwuje się ustępowanie tego objawu $[3,9,17]$.

U pacjentów z PChN może wystąpić ginekomastia, spowodowana zwiększonym wydzielaniem prolaktyny. Stężenie prolaktyny powyżej $30 \mu \mathrm{g} / 1$ bezpośrednio przyczynia się do pogorszenia funkcji nerek. U kobiet w wyniku hiperprolaktynemii następuje zahamowanie uwalniania hormonu luteinizującego oraz folikulotropowego, a tym samym zmniejszenie produkcji estrogenów i progesteronu, co sprzyja rozwojowi trądziku i/lub hirsutyzmu. Ponadto związana z hiperprolaktynemią insulinooporność może się przyczyniać do występowania rogowacenia ciemnego [3]. 
dialysis shunt area and occasionally leading to skin necrosis. They are caused primarily by increased skin fragility due to cutaneous thinning. Patients tend to be more prone to infections caused in about $80 \%$ of cases by Staphylococcus aureus, less commonly by Staphylococcus epidermidis, and in about $15 \%$ of cases by Gram-negative bacteria. Treatment should be based on a 4- to 6-week antibiotic regimen depending on the patient's antibiogram, combined with surgical wound management [3].

\section{SPECIFIC SKIN CHANGES IN PATIENTS WITH END-STAGE RENAL DISEASE}

\section{Acquired perforating dermatosis}

Perforating dermatoses are a group of heterogeneous skin conditions characterized by the transepidermal elimination of dermal substrates originating in deeper layers of the skin $[2,7,19,20]$. Acquired perforating dermatosis, also known as Kyrle's disease, has clinical and histopathological features resembling primary perforating dermatoses $[2,3$, $11,19]$. The disease, which is sometimes associated with diabetes mellitus, affects $2-11 \%$ of patients with ESRD, and its onset frequently coincides with the initiation of dialysis therapy $[2,6,7,9,19,21]$. The pathomechanism of the lesions has not been explained fully, however skin irritation and injury have been implicated as factors leading to inflammation and, as a consequence, triggering the lesions [2, 7, 19]. Clinical features of acquired perforating dermatosis include papules and nodules with central keratotic plugs, red or brown in colour depending on the patient's skin phototype $[3,9]$. Skin eruptions are most typically located on the extensor parts of the extremities and on the trunk, and may be accompanied by pruritus $[2,3,6,7,9,19]$. In addition, the Koebner phenomenon is observed in areas where the skin is readily exposed to injury, such as scratching $[2,3,6$, 19]. The changes may resolve spontaneously, leaving behind scarring, however there is a distinct tendency for skin eruptions to recur in the same locations [3, 6]. Diagnosis is aided by histopathological examination of a skin biopsy taken from a lesion with keratin plugs observed either in or around hair follicles, accompanied by parakeratosis and orthokeratosis $[3,20]$. Topical treatment is based on glucocorticosteroids (clobetasol propionate), keratolytic agents (salicylic acid, urea) and retinoids $[2,3,6,7,11]$. The efficacy of UVB $311 \mathrm{~nm}$ phototherapy and cryotherapy has also been reported [2, 3, 6, 7]. Another therapeutic option is based on oral antihistamine drugs (e.g. hydroxyzine), allopurinol, retinoids (acitretin) or doxycycline $[2,6,7]$.
Innymi objawami u pacjentów z PChN są zmiany zapalne skóry w okolicy przetok dializacyjnych, niekiedy prowadzące do martwicy skóry. Spowodowane są one głównie zwiększoną urażalnością wynikającą ze ścieńczenia skóry. Pacjenci są bardziej podatni na zakażenia, które w ok. $80 \%$ są wywołane przez Staphylococcus aureus, rzadziej Staphylococcus epidermidis, a w ok. 15\% przez bakterie Gram-ujemne. Leczenie tych zmian powinno być oparte na trwającej ok. 4-6 tygodni antybiotykoterapii zgodnej z antybiogramem w połączeniu z opracowaniem chirurgicznym rany [3].

\section{SWOISTE ZMIANY SKÓRNE U PACJENTÓW ZE SCHYŁKOWA NIEWYDOLNOŚCIA NEREK}

\section{Nabyta dermatoza perforująca}

Dermatozy perforujące tworzą grupę różnorodnych chorób skóry, charakteryzujących się przeznaskórkową eliminacją substratów skóry pochodzących z jej głębszych warstw $[2,7,19,20]$. Nabyta dermatoza perforująca, zwana również chorobą Kyrle'a, ma cechy kliniczne i histopatologiczne zbliżone do pierwotnych dermatoz perforujących $[2,3,11,19]$. Choroba, która niekiedy rozwija się u pacjentów z cukrzycą, występuje u 2-11\% chorych ze SNN, a jej początek często wiąże się z rozpoczęciem dializ $[2,6$, 7, 9, 19, 21]. Patomechanizm zmian nie został wyjaśniony, ale podejrzewa się znaczenie drażnienia i uszkodzenia skóry, które prowadzą do powstania stanu zapalnego, a w konsekwencji do wywołania zmian $[2,7,19]$. Klinicznie obserwuje się grudki i guzki z centralnym czopem rogowym, których zabarwienie czerwone lub brązowe zależy od fototypu skóry $[3,9]$. Wykwity chorobowe lokalizują się najczęściej na powierzchniach wyprostnych kończyn oraz na tułowiu, może towarzyszyć im świąd [2, 3, 6, 7, 9, 19]. Ponadto w miejscach narażonych na uraz (np. drapanie) obecny jest objaw Koebnera [2, 3, 6, 19]. Zmiany mogą ustępować samoistnie, pozostawiając blizny, niemniej istnieje znaczna tendencja do tworzenia w tych samych miejscach kolejnych wykwitów $[3,6]$. W ustaleniu rozpoznania pomocne jest badanie histopatologiczne wycinka skóry, w którym obserwuje się czopy keratynowe w mieszkach włosowych lub okołomieszkowo z towarzyszącą parakeratozą i ortokeratozą [3, 20]. W leczeniu miejscowym stosuje się glikokortykosteroidy (propionian klobetazolu), leki keratolityczne (kwas salicylowy, mocznik) oraz retinoidy $[2,3,6,7,11]$. Opisano skuteczność fototerapii UVB 311 nm i krioterapii [2, 3, 6, 7]. Można również zastosować doustne leki przeciwhistaminowe (np. hydroksyzynę), alopurynol, retinoidy (acytretynę) lub doksycyklinę $[2,6,7]$. 


\section{Bullous diseases, bullous dermatoses}

Patients with ESRD are affected by porphyria cutanea tarda and pseudoporphyria [2, 3, 6, 22]. Depending on the literature source, the incidence of both conditions in patients with ESRD varies between $1.2 \%$ and $9 \%$ [3]. They result from the accumulation of photosensitive substances in the skin [2]. Following exposure to UV radiation, patients develop skin lesions in the form of tense bullae followed by erosions and scabs on exposed skin areas, typically on the face, extensor surfaces of the forearms and dorsal hands $[2,3,6,7]$. The lesions heal, leaving behind atrophic scars and milia. Porphyria cutanea tarda is caused by the lack of uroporphyrinogen decarboxylase or various degrees of its deficiency [2, 3, 7]. In the acquired form of the disease, the deficiency of the enzyme is observed in hepatocytes, and in the inherited form also in other body cells, i.e. erythrocytes and fibroblasts $[3,6,7]$. Factors contributing to the dysfunction of the enzyme include alcohol consumption, iron supplementation, infection with hepatitis $\mathrm{C}$ virus (HCV) or human immunodeficiency virus (HIV) $[2,3,6,7]$. On account of the formation of porphyrin complexes with protein, which have a large molecular weight, conventional dialysis techniques are not always able to remove them effectively $[2,23]$. Porphyria cutanea tarda is less common in patients undergoing peritoneal dialysis which has a higher capacity to remove large molecules [2]. Characteristic features of porphyria cutanea tarda are hyperpigmentation and hypertrichosis in sun-exposed locations. Unlike pseudoporphyria, laboratory tests in porphyria cutanea tarda typically reveal increased plasma concentrations of uroporphyrin, iron and ferritin, and an elevated level of uroporphyrin in urine $[2,3,6,23]$. Histopathological examination of a skin biopsy in porphyria cutanea tarda shows subepidermal bullae with minor inflammatory infiltration, whereas a direct immunofluorescence assay demonstrates IgG and C3 deposits at the dermal-epidermal junction and in the vascular walls [3].

The prophylaxis of cutaneous lesions should involve avoidance of triggering factors and sun protection. One of available symptomatic treatment modalities is iron deposit reduction by the supply of erythropoiesis-stimulating agents and small volume phlebotomy (ca. 50-100 ml of blood/week). Patients with contraindications to phlebotomy may be treated with intravenous deferoxamine during each dialysis, however the benefits to the patient should always be weighed against the risk associated with adverse drug reactions $[2,3,6,7]$. Chloroquine is often prescribed as a substance increasing the solubility of porphyrins and facilitating their elimination in urine, however consideration should be given to the fact that it is ineffective in patients with anuria

\section{Choroby związane z tworzeniem pęcherzy}

U pacjentów ze SNN występuje porfiria skórna późna oraz pseudoporfiria $[2,3,6,22]$. Według różnych źródeł oba schorzenia występują u od 1,2\% do $9 \%$ pacjentów ze SNN [3]. Spowodowane są gromadzeniem światłoczułych substancji w skórze [2]. Po ekspozycji na promieniowanie UV na odsłoniętych częściach ciała, zazwyczaj na skórze twarzy, wyprostnych powierzchni przedramion i grzbietów rąk, powstają dobrze napięte pęcherze, a następnie nadżerki i strupy $[2,3,6,7]$. Zmiany goją się z pozostawianiem zanikowych blizn oraz prosaków. Porfiria skórna późna spowodowana jest brakiem lub różnego stopnia niedoborem dekarboksylazy uroporfirynogenu [2, $3,7]$. W postaci nabytej niedobór enzymu stwierdza się $w$ hepatocytach, natomiast $w$ postaci dziedzicznej również w innych komórkach organizmu, tj. erytrocytach i fibroblastach $[3,6,7]$. Wpływ na zaburzenia czynności enzymu ma m.in. spożywanie alkoholu, suplementacja żelazem, zakażenie wirusem zapalenia wątroby typu C (WZW typu C) lub ludzkim wirusem niedoboru odporności (HIV) [2, 3, 6, 7]. Ze względu na powstawanie kompleksów porfiryn $\mathrm{z}$ białkiem, które mają dużą masę cząsteczkową, konwencjonalne metody dializoterapii nie zawsze mogą je skuteczne usunąć $[2,23]$. Porfiria skórna późna rzadziej występuje u pacjentów poddawanych dializom otrzewnowym, które charakteryzują się większymi możliwościami eliminacji dużych cząsteczek [2]. Objawami charakterystycznymi dla porfirii skórnej późnej są hiperpigmentacja i hipertrychoza w miejscach narażonych na promieniowanie słoneczne, natomiast $\mathrm{w}$ badaniach laboratoryjnych typowe jest zwiększone stężenie w osoczu uroporfiryny, żelaza i ferrytyny, a w moczu uroporfiryny, czego nie stwierdza się $\mathrm{w}$ pseudoporfirii $[2,3,6,23]$. W badaniu histopatologicznym wycinka skóry w porfirii skórnej późnej obserwuje się podnaskórkowe pęcherze z niewielkim naciekiem zapalnym, natomiast $\mathrm{w}$ bezpośrednim badaniu immunofluorescencyjnym ziarniste złogi IgG i C3 na granicy skórno-naskórkowej oraz w ścianie naczyń [3].

Profilaktyka zmian powinna polegać na unikaniu czynników wyzwalających oraz na ochronie przeciwsłonecznej. Jedną z metod leczenia objawowego jest zmniejszanie zasobów żelaza poprzez suplementacje substancjami stymulującymi erytropoezę oraz wykonywanie upustów krwi o małej objętości (ok. 50$100 \mathrm{ml} /$ tydzień). U pacjentów z przeciwwskazaniami do upustów krwi podczas każdej dializy można zastosować deferoksaminę dożylnie, jednak należy rozważyć korzyści dla pacjenta i ryzyko związane z działaniami niepożądanymi $[2,3,6,7]$. Chlorochina jest często zalecaną substancją zwiększającą rozpuszczalność porfiryn i ułatwiającą ich wydalanie z moczem, należy jednak uwzględnić jej nieskuteczność 
$[3,6,7]$. Also, highly permeable dialysis membranes should be selected to ensure more efficient porphyrin elimination $[2,6]$. Similarly to other cutaneous manifestations of CKD, the symptoms resolve after kidney transplantation [6].

Since the clinical and histopathological features of pseudoporphyria and porphyria cutanea tarda are similar, the differentiation of the two disorders is based on assaying the porphyrin concentration in blood and urine $[2,3,7]$. The pathophysiological mechanism of pseudoporphyria is not fully understood [2]. There is a suspected link between the emergence of symptoms and some drugs. Therefore, certain medications including diuretics, antibiotics or antifungal chemotherapeutics should not be considered in therapeutic management $[2,3,6,22]$. As in porphyria cutanea tarda, appropriate sun protection is recommended $[2,6]$. Another potentially beneficial therapeutic agent is $\mathrm{N}$-acetylocysteine, a metabolic precursor of glutathione, with antioxidant properties $[2,7,22]$.

\section{Calcinosis}

Elevated blood serum concentrations of calcium lead to the formation of calcium and phosphate deposits in the skin, subcutaneous tissue, blood vessels and internal organs $[2,3,6,7,17]$. Hyperphosphataemia is an effect of a decreased glomerular filtration rate, and secondary hyperparathyroidism together with its associated increase in parathormone concentration contribute to the resorption of calcium and phosphates from bones [2, 6, 24]. As soon as their plasma solubility threshold is exceeded, calcium deposits begin to form in the skin, with a potential to evacuate spontaneously without accompanying tissue necrosis $[2,3,6,24]$. The clinical features include white papules and nodules on the skin over the joints and on the palmar surfaces of the fingers [2, 3, 6, 17] Periarticular lesions are mostly symptomless, however changes observed on the fingers may cause pain $[2,3,6,7,17]$. The severity of calcifications is positively correlated with increasing plasma levels of phosphates, and they have a tendency to regress along with decreases in phosphate concentrations. Patients are advised to follow a diet with a limited intake of phosphate-rich foods and use supplements binding the compounds in the gastrointestinal tract $[2,6,24]$.

\section{Calciphylaxis - calcific uraemic arteriolopathy}

Calcific uraemic arteriolopathy, also known as calciphylaxis (CPX), usually occurs at about 50 years of age, and its incidence varies from approximately $1 \%$ of patients with ESRD receiving conservative treatment to about $4 \%$ of dialysis patients $[2,3,6,25]$. Calciphylaxis is associated with high mortality (60- u pacjentów z bezmoczem [3, 6, 7]. Powinno się wybierać błony dializacyjne o wysokiej przepuszczalności, umożliwiające sprawniejsze wydalanie porfiryn $[2,6]$. Podobnie jak w przypadku innych objawów skórnych związanych z PChN ustąpienie dolegliwości następuje po przeszczepieniu nerki [6].

Ze względu na znaczne podobieństwo obrazu klinicznego i histopatologicznego pseudoporfirii oraz porfirii skórnej późnej ich różnicowanie polega na oznaczeniu stężenia porfiryn we krwi i moczu [2, 3 , 7]. Mechanizm powstania pseudoporfirii nie jest dobrze poznany [2]. Podejrzewa się, że za wywołanie objawów mogą być odpowiedzialne niektóre leki. Dlatego też w postępowaniu zaleca się unikanie takich preparatów, jak leki moczopędne, antybiotyki czy chemioterapeutyki przeciwgrzybicze $[2,3,6$, 22]. Podobnie jak w porfirii skórnej późnej zaleca się ochronę przeciwsłoneczną $[2,6]$. W leczeniu pomocna może być $\mathrm{N}$-acetylocysteina - metaboliczny prekursor glutationu o działaniu antyoksydacyjnym [2, $7,22]$.

\section{Zwapnienia}

Podwyższone stężenie wapnia w surowicy powoduje odkładanie w skórze, tkance podskórnej, naczyniach krwionośnych i narządach wewnętrznych złogów zawierających wapń i fosforany $[2,3$, $6,7,17]$. Hiperfosfatemia wynika ze zmniejszonego przesączania kłębuszkowego, a wtórna nadczynność przytarczyc i związane z tym zwiększone stężenie parathormonu przyczynia się do resorpcji wapnia i fosforanów z kości [2, 6, 24]. Po przekroczeniu progu ich rozpuszczalności w osoczu obserwuje się powstawanie w skórze zwapnień mogących ulegać samoistnej ewakuacji, bez towarzyszącej martwicy tkanek [2, 3, 6, 24]. W obrazie klinicznym stwierdza się występowanie białych grudek i guzków w skórze pokrywającej stawy oraz na dłoniowej powierzchni palców [2, 3, 6, 17]. Zmiany okołostawowe są najczęściej bezobjawowe, natomiast zmiany na palcach rąk mogą powodować ból [2, 3, 6, 7, 17]. Zwapnienia nasilają się wraz ze wzrostem stężenia fosforanów w osoczu i mają tendencję do cofania się, kiedy to stężenie się zmniejsza. Pacjentom zaleca się dietę z ograniczeniem pokarmów zawierających fosforany oraz stosowanie suplementów wiążących te związki w przewodzie pokarmowym $[2,6,24]$.

\section{Kalcyfilaksja - wapniejąca arteriolopatia mocznicowa}

Wapniejąca arteriolopatia mocznicowa, zwana również kalcyfilaksją (CPX), najczęściej pojawia się ok. 50. roku życia i dotyka od ok. 1\% pacjentów ze SNN leczonych zachowawczo do ok. $4 \%$ chorych poddawanych dializom $[2,3,6,25]$. Związana $z$ nią 
Table I. Calciphylaxic risk factors $[2,6,7,25,26]$

Tabela I. Czynniki ryzyka kalcyfilaksji (CPX) $[2,6$, 7, 25, 26]

\begin{tabular}{|c|c|}
\hline \multirow{9}{*}{$\begin{array}{l}\text { Modifiable factors/ } \\
\text { Czynniki modyfikowalne }\end{array}$} & Trauma/uraz \\
\hline & $\begin{array}{l}\text { Obesity (BMI }>30 \mathrm{~kg} / \mathrm{m}^{2} \text {, on account of large fatty tissue deposits which may be associated with } \\
\text { a reduction in local blood flow)/otyłość [wskaźnik masy ciała (BMI) > } 30 \mathrm{~kg} / \mathrm{m}^{2} \text {, ze względu na duże } \\
\text { depozyty tkanki tłuszczowej, co może być związane ze zmniejszeniem przeptywu miejscowego] }\end{array}$ \\
\hline & Liver diseases/choroby wątroby \\
\hline & $\begin{array}{l}\text { Insulin-dependent diabetes mellitus (extensive vascular calcifications)/cukrzyca insulinozależna (rozległe } \\
\text { zwapnienia naczyń) }\end{array}$ \\
\hline & Hypoalbuminaemia/hipoalbuminemia \\
\hline & Warfarin therapy/terapia warfaryną \\
\hline & Therapy with erythropoiesis-stimulating agents/leczenie substancjami stymulującymi erytropoezę \\
\hline & Systemic glucocorticosteroid therapy/glikokortykosteroidoterapia systemowa \\
\hline & Supplementation with calcium salts, iron and vitamin $\mathrm{D} /$ suplementacja solami wapnia, żelaza i witaminą $\mathrm{D}$ \\
\hline \multirow{2}{*}{$\begin{array}{l}\text { Non-modifiable factors/ } \\
\text { Czynniki niemodyfikowalne }\end{array}$} & Female gender/płeć żeńska \\
\hline & Caucasian race/rasa kaukaska \\
\hline
\end{tabular}

$80 \%)$ which is primarily due to septicaemia or internal organ dysfunction [2, 6, 25]. Multiple risk factors have been identified and divided into modifiable and non-modifiable categories (Table 1) [2, 6, 7, 25, 26]. The complex pathogenesis of the disease is thought to involve multiple proinflammatory cytokines including tumour necrosis factor $\alpha$ (TNF- $\alpha$ ), IL-1 and IL-6, and oxidative stress due to not only kidney failure but also coexisting diseases such as arterial hypertension, hypercholesterolaemia, obesity or type 2 diabetes [2, $3,6,7,26]$. All the disorders listed above are known to be characterized by the depletion of antioxidants, for example glutathione [2]. As a consequence, the vessel lumen is narrowed, and the blood flow rate is reduced, thus increasing the risk of parietal thrombus formation $[2,25]$. Also, the deposition of calcium salts is conducive to vascular wall fibrosis in small and medium-sized arteries [2, 7]. The role of parathormone (PTH) is not fully understood, since calciphylaxis has also been observed in patients with low PTH concentrations in the blood due to parathyroidectomy [25]. For this reason, the development of CPX cannot be excluded even if phosphate calcium and PTH levels in the blood are within the normal range $[2,6,7,25]$. The disease most commonly affects cutaneous blood vessels, however it may also involve the blood vessels in internal organs, leading to ischaemia of the heart muscle, intestines, lungs and muscles [2, 3, 25].

The involvement of blood vessels in the skin initially presents as mottled red-purple eruptions resembling livedo reticularis, which are accompanied by slight tenderness $[2,3,6,7,25,26]$. Over a period of several weeks, or occasionally days, these eruptions progress to form painful nodules surrounded śmiertelność (wynosząca 60-80\%) jest najczęściej spowodowana posocznicą lub niewydolnością narządów wewnętrznych $[2,6,25]$. Zidentyfikowano wiele czynników ryzyka, które podzielono na tzw. czynniki modyfikowalne i niemodyfikowalne (tabela 1) [2, 6, $7,25,26]$. W złożonej patogenezie choroby bierze się pod uwagę udział wielu cytokin prozapalnych, w tym czynnika martwicy nowotworów $\alpha$ (TNF- $\alpha$ ), IL-1 i IL6, oraz rolę stresu oksydacyjnego wynikającego nie tylko z niewydolności nerek, lecz także ze współwystępowania takich chorób, jak nadciśnienie tętnicze, hipercholesterolemia, otyłość i cukrzyca typu 2 [2, $3,6,7,26]$. Wiadomo, że w przebiegu tych zaburzeń dochodzi do zużycia antyoksydantów (przeciwutleniaczy), np. glutationu [2]. W konsekwencji następuje zwężenie światła naczynia i zmniejszenie szybkości przepływu krwi, co zwiększa ryzyko powstawania skrzeplin przyściennych $[2,25]$. Dodatkowo odkładanie soli wapnia sprzyja włóknieniu ścian małych i średnich tętnic $[2,7]$. Rola parathormonu (PTH) nie została dotychczas jednoznacznie określona, gdyż występowanie CPX obserwowano również u pacjentów z małym stężeniem PTH we krwi w związku z operacyjnym usunięciem przytarczyc [25]. $Z$ tego powodu prawidłowe wartości fosforanu wapnia i PTH we krwi nie wykluczają CPX [2, 6, 7, 25]. Choroba najczęściej dotyczy naczyń krwionośnych skóry, jednak może zajmować również naczynia krwionośne narządów wewnętrznych, co prowadzi do niedokrwienia mięśnia sercowego, jelit, płuc, mięśni [2, 3, 25].

Objawy wynikające z zajęcia naczyń skóry mają początkowo wygląd marmurkowatych wykwitów barwy czerwonofioletowej, przypominających siność siatkowatą, zmianom towarzyszy niewielka bolesność 
by bluish-purple borders, followed by skin necrosis and the development of an irregularly shaped painful ulcer with haemorrhagic bullae forming around its circumference $[2,7,25]$. The lesions are symmetrical, and usually appear on the lower extremities and in body areas containing abundant adipose tissue such as the abdomen and buttocks $[2,3,6,25,26]$. The involvement of blood vessels in the proximal parts of the extremities by the pathological process is associated with a markedly worse prognosis $[3,6,26]$. The histopathological picture which is characteristic (though not pathognomonic) of CPX shows discrete calcifications in small and medium-sized blood vessels in the skin and subcutaneous tissue accompanied by moderately severe inflammation. Features of adipose tissue inflammation and calcium deposits around adipocytes are also present $[2,3,26]$. Their detection is facilitated by additional staining with von Kossa's method. Also, the diagnosis of the extent of calcifications should preferably be supported by radiological imaging (radiography or computed tomography) [2]. Early correct diagnosis and initiation of therapeutic management may prevent the development of complications $[2,6,25]$. Since CPX is associated with impaired ulcer healing, immune abnormalities and multiple comorbidities, the risk of developing a systemic infection is considerably increased [25]. Prophylactic management is also important in order to prevent infection by appropriate wound care and surgical wound management $[2,3,6]$. Mechanical wound debridement, however, is not recommended in patients with dry gangrene and peripheral perfusion disorders, as a dry and intact scab may serve as an antibacterial barrier, functioning like a natural biological dressing [25]. Hyperbaric therapy, similarly to proper selection of biological dressings, accelerates the process of ulcer healing. Bacterial infections should be treated with antibiotic therapy, with the choice of antibiotic based on the patient's antibiogram $[2,3,6]$. Treatment can be based on bisphosphonates or sodium thiosulphate which regulate the calcium and phosphate balance $[2,6,27]$. Another important aspect is the assessment of risk of thromboembolic incidents resulting from an increased predisposition to hypercoagulability (protein C and S levels, antiphospholipid syndrome) and, where necessary, initiation of anticoagulation therapy (except for warfarin) [6].

\section{Nephrogenic systemic fibrosis}

Nephrogenic systemic fibrosis (NFS) most commonly affects patients aged about 50 years. It is caused by an increased collagen deposition in body tissues, manifesting as tissue hardening and thickening $[2,3,28,29]$. The aetiology of the disease involves, among other factors, body exposure to gadolinium-based contrast agents, low glomerular filtration
$[2,3,6,7,25,26]$. W czasie kilku tygodni lub niekiedy dni obserwuje się progresję wykwitów do bolesnych guzków otoczonych sinofioletową obwódką, a następnie martwicy skóry i powstania nieregularnego, bolesnego owrzodzenia, na którego obwodzie tworzą się krwotoczne pęcherze [2, 7, 25]. Zmiany są symetryczne, najczęściej obejmują kończyny dolne oraz okolice bogate w tkankę tłuszczową, takie jak brzuch i pośladki $[2,3,6,25,26]$. Zajęcie procesem patologicznym naczyń krwionośnych proksymalnych części kończyn znacznie pogarsza rokowanie [3, 6, 26]. W obrazie histopatologicznym, który jest charakterystyczny (ale nie patognomoniczny) dla CPX, obserwuje się dyskretne zwapnienia małych i średnich naczyń skóry i tkanki podskórnej, z miernie nasilonym stanem zapalnym. Obecne są również cechy zapalenia tkanki tłuszczowej oraz złogi wapnia wokół adipocytów $[2,3,26]$. W ich wykrywaniu pomocne jest zastosowanie dodatkowego barwienia metodą von Kossa. Ponadto w diagnostyce rozległości zwapnień zaleca się wykonanie radiologicznych badań obrazowych (rentgenogram lub tomografia komputerowa) [2]. Wczesne ustalenie prawidłowego rozpoznania i wdrożenie postępowania leczniczego może zapobiec rozwojowi powikłań [2, 6, 25]. W związku z upośledzonym gojeniem owrzodzeń u pacjentów z CPX i zaburzeniami immunologicznymi oraz licznymi chorobami towarzyszącymi znacznie wzrasta ryzyko rozwoju zakażenia ogólnoustrojowego [25]. Ważne jest postępowanie profilaktyczne mające na celu zapobieganie rozwojowi zakażenia poprzez prawidłową pielęgnację rany $i$ jej chirurgiczne opracowanie $[2,3$, 6]. Jednak u pacjentów z martwicą suchą oraz zaburzeniami perfuzji obwodowej nie zaleca się oczyszczania mechanicznego, gdyż suchy, nienaruszony strup może stanowić barierę przeciwbakteryjną, działając jak naturalny, biologiczny opatrunek [25]. Terapia hiperbaryczna, podobnie jak prawidłowy dobór opatrunków biologicznych, przyspiesza proces gojenia owrzodzeń. W przypadku infekcji bakteryjnej wskazane jest wdrożenie antybiotykoterapii zgodnej $z$ antybiogramem $[2,3,6]$. W leczeniu można zastosować bisfosfoniany lub tiosiarczan sodu, które regulują gospodarkę wapniowo-fosforanową $[2,6,27]$. Ważna jest również ocena ryzyka incydentów zatorowo-zakrzepowych spowodowanych predyspozycją do nadkrzepliwości (stężenie białka C i S, zespół antyfosfolipidowy), a w razie konieczności rozpoczęcie terapii przeciwkrzepliwej (z wykluczeniem warfaryny) [6].

\section{Nefrogenne włóknienie układowe}

Nefrogenne włóknienie układowe (NFS) najczęściej występuje u pacjentów w wieku ok. 50 lat. Spowodowane jest zwiększonym odkładaniem kolagenu w tkankach, objawiającym się ich stwardnieniem oraz pogrubieniem [2, 3, 28, 29]. Etiologia choroby wiąże 
rate (GFR), need for frequent dialysis treatments and dialysis type [2]. Nephrogenic systemic fibrosis is known to occur exclusively in patients with GFR < $30 \mathrm{ml} / \mathrm{min}$ secondary either to acute or chronic kidney failure $[2,28]$. The association with the use of gadolinium-based magnetic resonance imaging contrast agents is due to their increased half-life (to about 60 hours), which is observed in patients with CKD $[2,3,6,11,28,29]$. It leads to the formation of toxic ionic forms including phosphates which, deposited in tissues, are phagocytosed by macrophages $[2,6$, 28 ]. The process results in the direct activation of circulating fibrocytes which, being involved in wound healing and post-inflammatory fibrosis, accumulate in damaged tissues and inflammation sites $[2,6,28$, 30]. Proinflammatory factors additionally increase the number of circulating fibrocytes [2]. The pathogenesis of fibrosis is known to involve cytokines such as the transforming growth factor $\beta$ (TGF- $\beta 1$ ) and platelet-derived growth factor (PDGF) $[2,30]$. The clinical picture of the disease is characterized by painful symmetrically distributed erythematous-oedematous lesions as well as papules, plaques and nodules [2,3, $6,7,28]$. Skin hyperpigmentation and hypopigmentation may also be present $[2,3,28]$. The main areas affected by eruptions include the lower extremities and, less commonly, the trunk and upper extremities. In periarticular areas they may lead to contractures $[2,3,6,7,11,28,29]$. Yellow-coloured papules occur on the palmar surfaces of the hands [3]. Skin manifestations are sometimes accompanied by pain, stinging or itching [2, 3, 7, 28, 29]. The process of pathological fibrosis may also involve internal organs, i.e. the lungs, heart, kidneys and liver [2, 6, 28, 29]. Rarely, the disease takes a fulminant course lasting several weeks [2, 29]. Histopathological examination of a skin biopsy shows the presence of thickened bundles of collagen and proliferation of spindle cells accompanied by mild inflammation, with mostly unchanged epidermis $[2,30]$. Available therapeutic options include UVA phototherapy, glucocorticosteroids, plasmapheresis, high-dose intravenous immunoglobulin G treatment, methotrexate or pentoxifylline [2, 6, 7]. Physiotherapeutic procedures prevent the development of contractures and make it possible to increase the range of joint motion [2, 6, 29]. High hopes are being placed on the use of biologic drugs such as imatinib [2]. Gadolinium-based contrast agents should be avoided as a means of CKD prevention. If, however, their use is necessary, two additional haemodialysis sessions should be scheduled - one within 2 hours of the administration of the contrast agent, so that gadolinium can be eliminated in over $90 \%[6,29]$. Some authors suggest that the use of iron supplements and erythropoiesis stimulators should be stopped a week before the scheduled examination [6]. The lesions się między innymi z ekspozycją na kontrast z gadolinem, niską wartością wskaźnika przesączania kłębuszkowego (GFR), koniecznością częstszych dializ oraz ich rodzajem [2]. Wiadomo, że NFS dotyczy wyłączenie pacjentów z GFR < $30 \mathrm{ml} / \mathrm{min}$, zarówno w przebiegu ostrej, jak i przewlekłej niewydolności nerek [2, 28]. Związek ze stosowaniem kontrastu z gadolinem, który jest wykorzystywany podczas rezonansu magnetycznego, wynika z wydłużonego okresu jego półtrwania do ok. 60 godzin, co obserwuje się u pacjentów z PChN [2, 3, 6, 11, 28, 29]. Prowadzi to do powstawania toksycznych jonowych form, w tym fosforanów, które odkładane w tkankach są fagocytowane przez makrofagi $[2,6,28]$. Powoduje to bezpośrednią aktywację krążących fibrocytów, które biorąc udział w gojeniu ran oraz we włóknieniu pozapalnym, gromadzą się w uszkodzonych tkankach oraz miejscach stanu zapalnego [2, 6, 28, 30]. Czynniki prozapalne dodatkowo zwiększają liczbę krążących fibrocytów [2]. Wiadomo, że w patogenezie włóknienia odgrywają rolę cytokiny, takie jak transformujący czynnik wzrostu $\beta 1$ (TGF- $\beta 1$ ) i płytkopochodny czynnik wzrostu (PDGF) $[2,30]$. W obrazie klinicznym obserwuje się bolesne, symetrycznie rozmieszczone zmiany rumieniowo-obrzękowe, a także grudki, blaszki i guzki [2, 3, 6, 7, 28]. Mogą być obecne przebarwienia i odbarwienia skóry $[2,3$, 28]. Wykwity zlokalizowane są głównie na kończynach dolnych, rzadziej na tułowiu i kończynach górnych. W okolicach okołostawowych mogą prowadzić do przykurczów [2, 3, 6, 7, 11, 28, 29]. Na dłoniowej powierzchni rąk występują grudki o żółtym zabarwieniu [3]. Zmianom skórnym niekiedy towarzyszy ból, pieczenie lub świąd [2, 3, 7, 28, 29]. Proces patologicznego włóknienia może obejmować również narządy wewnętrzne, tj. płuca, serce, nerki i wątrobę $[2,6,28,29]$. Rzadko stwierdza się piorunujący, kilkutygodniowy przebieg choroby $[2,29]$. W obrazie histopatologicznym wycinka skóry widoczne są zagęszczone wiązki włókien kolagenowych oraz proliferacja komórek wrzecionowatych z towarzyszącym nieznacznym stanem zapalnym, naskórek zazwyczaj jest niezmieniony $[2,30]$. W leczeniu stosuje się fototerapię UVA, glikokortykosteroidy, plazmaferezy, duże dawki dożylnych immunoglobulin $\mathrm{G}$, metotreksat lub pentoksyfilinę [2, 6, 7]. Zabiegi fizykoterapeutyczne zapobiegają rozwojowi przykurczów oraz pozwalają na zwiększenie zakresu ruchomości stawów [2, 6, 29]. Duże nadzieje wiąże się z zastosowaniem leków biologicznych, np. imatynibu [2]. W profilaktyce PChN powinno się unikać kontrastu z gadolinem. W przypadku konieczności jego zastosowania wskazane jest zaplanowanie dodatkowych dwóch sesji hemodializ - pierwszej w czasie 2 godzin od podania kontrastu, co umożliwi eliminację gadolinu w ponad $90 \%$ [6, 29]. Niektórzy autorzy sugerują, że podawanie prepara- 
have been observed to resolve spontaneously in several patents with acute renal failure. Furthermore, the severity of the disease seems to decrease along with improvements in kidney function [2, 6, 7, 28, 29].

Patients with CKD relatively frequently present with skin manifestations which may become increasingly severe over the duration of the disease. Additional factors which may play a role in their development are medications used by the patient. Specific and non-specific skin changes are a significant diagnostic and therapeutic problem. As a result, patients with chronic kidney failure require multidisciplinary medical management including dermatological care. As new therapeutic methods are developed to prevent the effects of chronic kidney disease, they contribute to the elimination or reduced severity of some cutaneous manifestations. However, skin lesions of this origin sometimes do not regress until kidney transplantation.

\section{CONFLICT OF INTEREST}

The authors declare no conflict of interest. tów żelaza oraz stymulatorów erytropoezy powinno zostać wstrzymane tydzień przed planowanym badaniem [6]. Obserwowano spontaniczne ustępowanie zmian u kilku pacjentów z ostrą niewydolnością nerek. Ponadto wydaje się, że nasilenie choroby zmniejsza się wraz z poprawą funkcji nerek [2, 6, 7, 28, 29].

U pacjentów z PChN dość często występują zmiany skórne, których nasilenie może się zwiększać wraz z czasem trwania choroby. Dodatkowo na ich wystąpienie mogą mieć wpływ leki stosowane przez pacjenta. Swoiste i nieswoiste zmiany skórne stanowią istotny problem diagnostyczny i leczniczy. W związku z tym pacjenci z przewlekłą niewydolnością nerek wymagają wielospecjalistycznej opieki, również dermatologicznej. Rozwój nowych metod leczniczych zapobiegających skutkom przewlekłej choroby nerek ogranicza występowanie lub nasilenie niektórych objawów skórnych, jednak niejednokrotnie zmiany skórne rozwijające się na tym podłożu ustępują jedynie po przeszczepieniu nerki.

\section{KONFLIKT INTERESÓW}

Autorzy deklarują brak konfliktu interesów.

\section{References}

\section{Piśmiennictwo}

1. Taal M.W.: Chronic kidney disease: towards a risk-based approach. Clin Med (Lond) 2016, 16, 117-120.

2. Galperin T.A., Cronin A.J., Leslie K.S.: Cutaneous manifestations of ESRD. Clin J Am Soc Nephrol 2014, 9, 201-218.

3. Lupi O., Rezende L., Zangrando M., Sessim M., Silveira C.B., Sepulcri M.A., et al.: Cutaneous manifestations in end-stage renal disease. An Bras Dermatol 2011, 86, 319-326.

4. Tajbakhsh R., Dehghan M., Azarhoosh R., Haghighi A.N., Sadani S., Zadeh S.S., et al.: Mucocutaneous manifestations and nail changes in patients with end-stage renal disease on hemodialysis. Saudi J Kidney Dis Transpl 2013, 24, 36-40.

5. Hajheydari Z., Makhlough A.: Cutaneous and mucosal manifestations in patients on maintenance hemodialysis: a study of 101 patients in Sari, Iran. Iran J Kidney Dis 2008, 2, 86-90.

6. Shafiee M.A., Akbarian F., Memon K.K., Aarabi M., Boroumand B.: Dermatologic manifestations in end-stage renal disease. Iran J Kidney Dis 2015, 9, 339-353.

7. Cordova K.B., Oberg T.J., Malik M., Robinson-Bostom L.: Dermatologic conditions seen in end-stage renal disease. Semin Dial 2009, 22, 45-55.

8. Shrestha P., Mathur M.: Dermatologic manifestations in chronic kidney disease patients on hemodialysis. Nepal J Dermatol Venereol Leprol 2014, 12, 34-40.

9. Udayakumar P., Balasubramanian S., Ramalingam K.S., Lakshmi C., Srinivas C.R., Mathew A.C.: Cutaneous manifestations in patients with chronic renal failure on hemodialysis. Indian J Dermatol Venereol Leprol 2006, 72, 119-125.

10. Szepietowski J.C., Reich A., Schwartz R.A.: Uraemic xerosis. Nephrol Dial Transplant 2004, 19, $2709-2712$.

11. Picó M.R., Lugo-Somolinos A., Sánchez J.L., Burgos-Calderón R.: Cutaneous alterations in patients with chronic renal failure. Int J Dermatol 1992, 31, 860-863.

12. Wang H., Yosipovitch G.: New insights into the pathophysiology and treatment of chronic itch in patients with end-stage renal disease, chronic liver disease, and lymphoma. Int J Dermatol 2010, 49, 1-11.

13. Narita I., Alchi B., Omori K., Sato F., Ajiro J., Saga D., et al.: Etiology and prognostic significance of severe uremic pruritus in chronic hemodialysis patients. Kidney Int 2006, 69, 1626-1632.

14. Keithi-Reddy S.R., Patel T.V., Armstrong A.W., Singh A.K.: Uremic pruritus. Kidney Int 2007, 72, 373-377.

15. Razeghi E., Tavakolizadeh S., Ahmadi F.: Inflammation and pruritus in hemodialysis patients. Saudi J Kidney Dis Transpl 2008, 19, 62-66.

16. Jamal A., Subramanian P.T., Hussain K.S.: Nail changes in end-stage renal failure patients on hemodialysis. Saudi J Kidney Dis Transpl 2000, 11, 44-47.

17. Avermaete A., Altmeyer P., Bacharach-Buhles M.: Skin changes in dialysis patients: a review. Nephrol Dial Transplant 2001, 16, 2293-2296.

18. Sharma V., Kumar V.: Muehrcke lines. CMAJ 2013, 185, E239.

19. Hong S.B., Park J.H., Ihm C.G., Kim N.I.: Acquired perforating dermatosis in patients with chronic renal failure and diabetes mellitus. J Korean Med Sci 2004, 19, 283-288.

20. Gliński W.: Nabyte schorzenia kolagenu i elastyny. [In:] Dermatologia. W.H.C. Burgdorf, G. Plewig, H.H Wolff, M. Landthaler M (eds.), Czelej, Lublin 2011, II, 719. 
21. Saray Y., Seçkin D., Bilezikçi B.: Acquired perforating dermatosis: clinicopathological features in twenty-two cases. J Eur Acad Dermatol Venereol 2006, 20, 679-688.

22. Kurban M.S., Boueiz A., Kibbi A.G.: Cutaneous manifestations of chronic kidney disease. Clin Dermatol 2008, 26, 255-264.

23. Balwani M., Desnick R.J.: The porphyrias: advances in diagnosis and treatment. Blood 2012, 120, 4496-4504.

24. Saliba W., El-Haddad B.: Secondary hyperparathyroidism: pathophysiology and treatment. J Am Board Fam Med 2009, 22, 574-581.

25. Martin R.: Mysterious calciphylaxis: wounds with eschar - to debride or not to debride? Ostomy Wound Manage 2004, 50, 64-71.

26. Mathur R.V., Shortland J.R., El Nahas A.M.: Calciphylaxis. Postgrad Med J 2001, 77, 557-561.

27. Zitt E., Konig M., Vychytil A., Auinger M., Wallner M., Lingenhel G., et al.: Use of sodium thiosulphate in a multi-interventional setting for the treatment of calciphylaxis in dialysis patients. Nephrol Dial Transplant 2013, 28, 1232-1240.

28. Zou Z., Zhang H.L., Roditi G.H., Leiner T., Kucharczyk W., Prince M.R.: Nephrogenic systemic fibrosis: review of 370 biopsy-confirmed cases. JACC Cardiovasc Imaging 2011, 4, 1206-1216.

29. Schlaudecker J.D., Bernheisel C.R.: Gadolinium-associated nephrogenic systemic fibrosis. Am Fam Physician 2009, 80, 711-714.

30. Quan T.E., Cowper S., Wu S.P., Bockenstedt L.K., Bucala R.: Circulating fibrocytes: collagen-secreting cells of the peripheral blood. Int J Biochem Cell Biol 2004, 36, 598-606.

Received: 17.02 .2017

Accepted: 28.03.2017

Otrzymano: $17.02 .2017 \mathrm{r}$

Zaakceptowano: 28.03 .2017 r.

How to cite this article

Przepiórka-Kosińska J.M., Chyl-Surdacka K.M., Bartosińska J., Krasowska D., Chodorowska G.: Skin changes in chronic kidney disease. Dermatol Rev/Przegl Dermatol 2017, 104, 142-153. DOI: https://doi.org/10.5114/dr.2017.67389 